\title{
Mucosal Patch on Tongue Due to Early Syphilis
}

\author{
Itaru Nakamura
}

Key words: Mucosal patch, early syphilis, oral

\author{
(Intern Med Advance Publication) \\ (DOI: 10.2169/internalmedicine.7691-21)
}

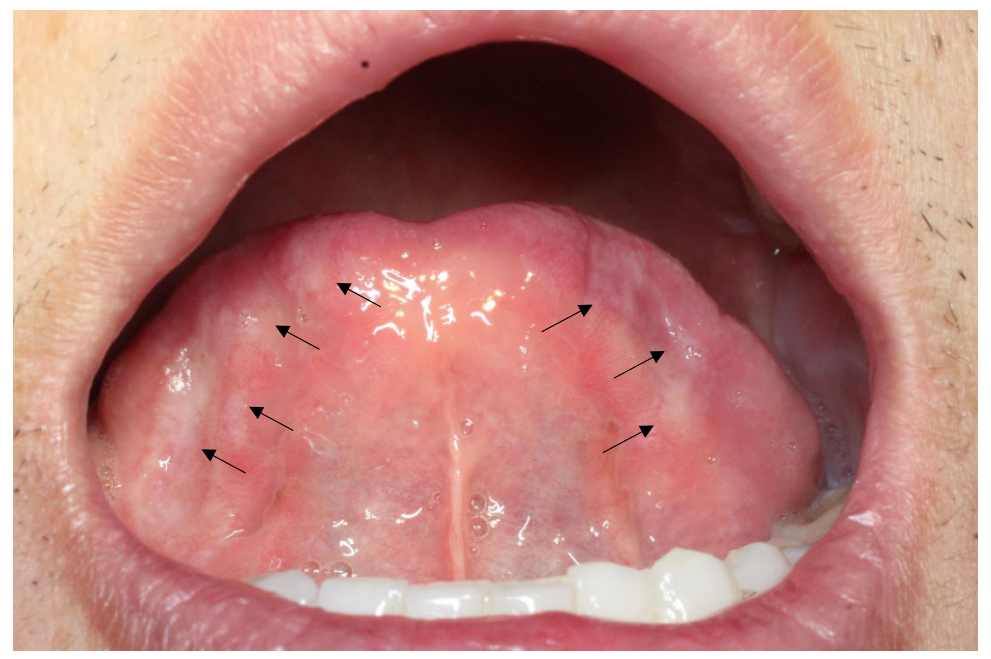

Picture.

A 43-year-old man presented with tongue pain persisting for 2 months. A mucosal patch on the underside and tip of the tongue without any nodule was observed (Panel A). No abnormal findings were observed in the lymph nodes. The patient had been taking anti-retroviral treatment for human immunodeficiency virus infection for over 10 years. The CD 4 counts and HIV-RNA load were $708 / \mu \mathrm{L}$ and undetected, respectively. Two months prior to the symptom onset, the patient had had unprotected oral sexual contact with a man. RPR test findings were elevated, at 330 R.U. After the administration of amoxicillin at $1.5 \mathrm{~g}$ per day for 14 days, combined with probenecid at $600 \mathrm{mg}$ per day for 14 days, all symptoms abated. The final diagnosis was a mucosal patch due to syphilis. Mucosal syphilis is too non-specific to remember the differential diagnosis (1). Clinicians need to inquire about patients' sexual history as a clue to diagnosing mucosal syphilis.

The author states that he has no Conflict of Interest (COI).

\section{Reference}

1. Hook EW. Syphilis. Lancet 389: 1550-1557, 2017.

The Internal Medicine is an Open Access journal distributed under the Creative Commons Attribution-NonCommercial-NoDerivatives 4.0 International License. To view the details of this license, please visit (https://creativecommons.org/licenses/ by-nc-nd/4.0/). 